\title{
Pietist tracts in SWEdish, PRINTED AT REVAL/TALLINN IN THE EARLY EIGHTEENTH CENTURY: BACKGROUND AND BIBLIOGRAPHICAL CAREER
}

Jürgen Beyer

\begin{abstract}
Between 1718 and 1726, the printer Johann Köhler at Reval/Tallinn produced about seventeen fairly small books of pietist persuasion in Swedish. It has generally been assumed that these books were meant to be smuggled into Sweden and Finland where the authorities would not allow the printing of such literature. Furthermore, bibliographers have attributed some other books of that ilk, but not indicating the printer, to Köhler. The article, firstly, shows what is known about the provenance of the extant copies. This suggests that the books might not have been produced for the Swedish and Finnish markets in the first place but rather for readers in Estonia and Russia. Secondly, the article argues, primarily on typographical grounds, that the attributions are unfounded. They were probably made because collectors since the eighteenth century had cherished books suppressed by the authorities as rare books. These attributions have been repeated and added to by generations of bibliographers and scholars. The author calls for a critical reassessment of attributions, not only in the Reval case but also concerning more important centres of clandestine publishing such as Amsterdam. The article concludes with a bibliography of Köhler's books published in Swedish, including the attributed titles.
\end{abstract}

Keywords: History of printing, history of books, bibliography, pietism

Authorities have always been tempted to restrict access to information they considered to be undesirable. The resulting censorship had an effect not normally considered by those in power: Books surviving in a few copies only or in mutilated form because of state or church interventions quickly turned into book collectors' items. As the number of such books, in part

The research on this article has been funded by the target funded research project SFo180040so8 at Tartu University Library, the development fund at Tartu University and grant 9178 of the Estonian Science Foundation. 
due to the efficiency of the censors, was rather small, bibliophiles and bibliographers were tempted to extend their searches to books assumed to have been suppressed which in turn led to some very problematic pieces of bibliographical information, as will be shown in the following case of transnational book history concerning Swedish books produced in Estonia under Russian rule by a German printer.

Research on Swedish ecclesiastical history has long been familiar with a series of pietist tracts from Reval. These were about seventeen - the counts vary somewhat - fairly small books (between 14 and 154 pages long), printed in Swedish at Reval by Johann Köhler between 1718 and $1726 .{ }^{1}$ The standard study on these tracts is still a thorough thesis on Swedish pietist literature published more than half a century ago by Ove Nordstrandh. ${ }^{2}$ The Reval tracts seem to form an exception in Estland's and Livland's long history of printing in Swedish. ${ }^{3}$ While the remaining production was directed at a local market, the Reval tracts are generally believed to have been produced for readers in Sweden and Finland. ${ }^{4}$ Finland - it might be necessary to mention - belonged to Sweden until 1809 and used Swedish as language of administration. Both in Finland and in Estonia a small part of the population consisted of native speakers of Swedish. The tracts are thought to have been published at Reval in order to avoid censorship in Sweden, taking advantage of the fact that Reval had belonged to the Swedish empire until the Russian conquest of 1710 and that the printing house still had expertise in printing in Swedish. The Reval tracts would then be smuggled to Sweden and Finland.

Knowledge about this mechanism appears to be widespread among Swedish church historians, but the exact circumstances seem to have been

\footnotetext{
${ }^{1}$ For bibliographical data on the Reval tracts - genuine and spurious - see the appendix. 2 Ove Nordstrandh, Den äldre svenska pietismens litteratur (diss. Lund) (Stockholm: Svenska kyrkans diakonistyrelses bokförlag, 1951).

3 Cf. Jürgen Beyer, "Om anvendelsen af det svenske sprog i Estland og Livland i 160oog 170o-tallet,” Svenska språkets historia i östersjöområdet, ed. by Svante Lagman, Stig Örjan Ohlsson and Viivika Voodla (Tartu: Tartu Ülikooli kirjastus 2002), 59-80; id., "Schwedische Lesestoffe in Est- und Livland im 17. und 18. Jahrhundert," Books and libraries in the Baltic Sea region from the $16^{\text {th }}$ to the $18^{\text {th }}$ century, ed. by Lea Kõiv and Tiiu Reimo (Tallinn: Tallinn City Archives \& Academic Library of Tallinn University, 2006), 165-171, briefly mentioning the Reval tracts on pp. 76 and 169 respectively.

4 Liivi Aarma, "Rääveli traktaadid," Raamat on ... Eesti bibliofilia ja raamatuajaloo almanahh, 1 (2000), 68-78 (70), claims that in three Finnish towns six book inventories altogether list Lähra om Begynnelsen (1718). Unfortunately, however, this information could not be retraced in the source quoted by her: Erkki Kansanaho, Hallen pietismin vaikutus Suomen varhaisempaan herännäisyyteen: teologianhistoriallinen tutkielma (diss. Helsinki) (Helsinki: Suomalainen teologinen kirjallisuusseura, 1947), 73.
} 
forgotten. The most recent standard history of the church in Sweden, for instance, states quite generally for the entire eighteenth century that authors failing to obtain approval from theological censors in Sweden could always get their books printed at Reval! ${ }^{5}$

\section{Translators, editors and book owners}

The assumption that the Reval tracts aimed at circumventing censorship in Sweden sounds plausible, and Nordstrandh provides some examples of Swedish authorities trying to prevent the circulation of such tracts in Sweden, ${ }^{6}$ but I should like to point out a few things speaking against it.

Most of the Reval tracts are translations from German. Nearly all translators remain anonymous but in those cases where we do know the translator or at least the editor, he did not live in Sweden, with the possible exception of the person translating the first tract, Caspar Neumann's "Oförgripelige Betänckiande Öfwer de i Schlesien offentligen Bedjande Barnen" [Humble opinion on the publicly praying children in Silesia] (1708) The translator is given on the title page as "JOH. WITTE". Since a suitable person with this name was not known to bibliographers, they instead concluded that the translator must have been the Joachim Witte who at the time taught at Kalmar grammar school. He published occasional poetry and two sermons but no translations. ${ }^{7}$ However, as will be shown in the following, this tract was not printed at Reval and therefore the exact identity of the translator needs not to be pursued any further here.

Axel Julius Herlin appears on the title pages of two Reval tracts, "LEsprit egaré [sic] du Monde" (1724) and "Några Wälmente ... Påminnelser" [Some well-meaning reminders] (1726), as having seen the books through the press. In the case of the book with the short-title in French - which was originally published in German but with the same French short-title ${ }^{8}$ the wording of the title page might be understood as Herlin also having translated the

\footnotetext{
5 Harry Lenhammar, "Själaskatt och Himmelsk kärlekskyss - 17oo-talets andaktslitteratur," Sveriges kyrkohistoria, 5: Individualismens och upplysningens tid, ed. id. (Stockholm: Verbum, 200o), 244-253 (245).

6 Cf. also Prästeståndets riksdagsprotokoll, 7: 1726-1731, ed. by Axel Norberg (Stockholm: Norstedts tryckeri, 1975), 26, 471, 527, published many years after Nordstrandh's book was printed.

7 Bror Olsson, Kalmar stifts herdaminne: det gamla kalmarstiftets klerus från äldsta tider till våra dagar, 3 (Kalmar: Dillbergska bokhandeln, 1948), 24-27.

${ }_{8}$ [Otto Heinrich Becker,] L'Esprit egaré [sic] du Monde Das ist / Das verkehrte Urtheil der Welt in Geistlichen Dingen ... (Amsterdam: Henrich Betkii Erben, 1710). The imprint "Amsterdam" is possibly fictitious, cf. Nordstrandh, Den äldre svenska pietismens
} 
text. ${ }^{9}$ Axel Julius Herlin's father, an immigrant from Sweden, had served as pastor for the Swedish-speaking congregation at Reval. ${ }^{10}$

In her biographical dictionary on pastors having served in Estland, Liivi Aarma states that Herlin took up a position as curate at the Swedish church in Reval in $1711{ }^{11}$ Aarma probably misunderstood an undated note in the preceding work on pastors in Estland by Hugo Richard Paucker, mentioning that the consistory refused to approve a son of Gabriel Herlin as curate at the Swedish church in Reval. ${ }^{12}$ This, in fact, applies to Gabriel Herlin jun. and the years 1708 to $1710 .^{13}$ Aarma dates Axel Julius Herlin's birth to $c .1687$. Her guess is as good as any other, since she as a rule subtracts 20 years from the date for the first matriculation at university (which in Herlin's case took place on 19 July 1707 at the University of Dorpat/Tartu, at the time relocated to Pernau/Pärnu). ${ }^{14}$ However, the Christian names Axel Julius did not occur in the family before. Assumedly, Herlin received these names in honour of his possible godfather, the governor-general of Estland, Axel Julius de la Gardie. ${ }^{15}$ De la Gardie was appointed to the post on 13 July 1687, but did not move to Reval before the summer of $1690,{ }^{16}$ which thus seems to be the terminus post quem for Herlin's birth.

litteratur, 105. Aarma believes the original to have been in French (Aarma, Põhja-Eesti vaimulike lühielulood, no. 395; ead., "Rääveli traktaadid," 71).

9 Cf. also Nordstrandh, Den äldre svenska pietismens litteratur, 106.

10 Peter Herlin is more likely than his brother Gabriel to have been the father of Axel Julius, cf. Arvo Tering, Lexikon estländischer, livländischer und kurländischer Studenten an europäischen Universitäten 1561-180o, ed. by Jürgen Beyer (Cologne: Böhlau, in preparation). Further genealogical data, not necessarily correct, can be found in Nils Herlin, "Herlin," in Släktbok. N. S., vol. 2, ed. by Ingegerd Lundén Cronström and Jarl Pousar (Helsinki: Svenska litteratursällskapet i Finland, 19[65-]77), 321-368, here 343-344. 11 Liivi Aarma, Põhja-Eesti vaimulike lühielulood 1525-1885 (Tallinn: [Aarma Maja], 2007), no. 395.

$12 \mathrm{H}$ [ugo] R[ichard] Paucker, Ehstlands Geistlichkeit in geordneter Zeit- und Reihefolge [sic] (Lindfors Erben, 1849), 377: "Gabriel Herlin's Sohn, vielleicht Axel Julius Herlin, später zu St. Jacobi, wurde vom Consistorio als Diaconus an der St. Michaelis-Kirche verworfen, wahrscheinlich weil er Pietist war, ja ihm sogar die Kanzel verboten." Already Ewert Wrangel, Frihetstidens odlingshistoria: ur litteraturens häfder 1718-1733 (Lund: C. W. K. Gleerup, 1895), 53, seems to have misunderstood this passage. He writes (without any references): "Axel Julius Herlin, hvilken såsom varande pietist af konsistoriet i Reval länge förbjudits predika, men 1719 erhållit S. Jacobs pastorat, utgaf 1724 en öfversättning af en fransk [sic] bok "Werldenes Wrångvisa Omdöme om Andeliga Saker" och 1726 "Påminnelser angående Christendomens förbättring"."

13 Cf. Arvo Tering, Album academicum der Universität Dorpat (Tartu) 1632-1710 (Tallinn: Valgus, 1984), no. 1558.

14 Tering, Album academicum, no. 1660.

15 I am grateful to Arvo Tering (Tartu) for this suggestion.

16 G. Jacobson, "Axel Julius De la Gardie," Svenskt biografiskt lexikon, 10 (Stockholm: Albert Bonnier, 1931), 709-717 (712). 
Herlin matriculated at Halle University on 15 September 1710 and stayed there for almost seven years. ${ }^{17}$ During these years he left rather many traces for a student: He was friendly with the Halle scholar Heinrich Milde (16761739) who had a keen interest in foreign languages. ${ }^{18}$ In a Swedish ecclesiastical handbook of which Milde used the front fly-leaves as a kind of album amicorum, Herlin left an entry in Swedish, probably after 3 March $1715 .{ }^{19}$ When his fellow student Johann Andreas Wiegleb died on 30 October 1716, he published a commemorative poem. ${ }^{20}$ On 9 January 1717 , Herlin made an entry in the album amicorum of Christoph Heinrich Helmershausen, ${ }^{21}$ and, shortly later, probably on 15 January, he gave a Tallinn-Estonian ecclesiastical handbook to Milde. ${ }^{22}$ After leaving Halle on 3 August $1717,{ }^{23}$ Herlin returned to Estland and eventually took up a post in 1719 as pastor of the Estonian-speaking congregation at St. Jakobi/Viru-Jaagupi. His university education had thus been German, not Swedish, but as one of his entries in the album amicorum shows, he was capable of writing in Swedish.

\footnotetext{
17 Fritz Juntke and Franz Zimmermann, Matrikel der Martin-Luther-Universität HalleWittenberg, 1: 1690-1730 (Halle: Universitäts- und Landesbibliothek, 1960), 219.

18 Cf. Alfred Mietzschke, Heinrich Milde: ein Beitrag zur Geschichte der slavistischen Studien in Halle (Leipzig: Otto Harrassowitz, 1941).

19 En Christens Gyllende Clenodium, Eller Siäle=Skatt Innehållandes the Böcker och Stycken som fölliande Bladh vthwijsar ... (Gothenburg: Larß Lönbohm, 1683) (Halle, Bibliothek der Franckeschen Stiftungen, $44 \mathrm{H} \mathrm{22}$ ). Herlin's entry reads: "HErrans Hemligheet är ibland them, som Honom fruchta, och sitt Förbund låter Han them få wetta. Ps. XXV. 14. Med deße Davids Ord hafwer welat sitt stadige Åminne den mÿcket älskelige Ägaren af denna Bocken, jämte tiänstl. Begiäran aldrig uti deß trogna Forböön mig at forgiäta, recommendera Ax. Jul. Herlin.”

20 Axel Julius Herlin, Das Leben im Tode ... (Halle: mit Salfeldischen Schrifften, [1716]). There is a copy at the Bibliothek der Franckeschen Stiftungen in Halle, but during my visit in August 2013 it was sent away for digitization and has not yet been made available online. On Wiegleb, cf. Matrikel der Martin-Luther-Universität Halle-Wittenberg, vol. 1, 480.

${ }_{21}$ Tering, Lexikon estländischer, livländischer und kurländischer Studenten.

22 Halle, Bibliothek der Franckeschen Stiftungen: $26 \mathrm{H}$ 9, the entry on the fly-leaf reads: "Ego vobis adfuturus sum perpetuo usque ad finem seculi. dicit Salvator. Amico suo honoratissimo Domino Henrico Milde donat hunc librum Axelius Julius Herlin." The volume contains, in this order, the numbers 63, 76, 64, 65, 66 and 67 in Eestikeelne raamat 1525-1850, ed. by E[ndel] Annus (Tallinn: Eesti Akadeemiline Raamatukogu, 200o), but the bibliography does not record the Halle copies.

23 Johann Jacob Rambach, Abschieds=Gedancken / Welche / Als ... Axel Julius Herlin / REVALIA-LIVONVS, S. THEOL. CANDIDATVS, Von der Königl. Preußl. [sic] Friedrichs=Universität $z$ u Halle / Auf welcher Er in die 7. Jahr seine Studia rühmlich getrieben / Dem [sic] 3ten Augusti 1717. Wieder in sein geliebtes Vaterland zurück reisete / Zu Bezeugung seiner auffrichtigen Freundschafft ... entworfen ... (Halle: Joh. Christian Hendel [1717]).
} 
The first Reval tract proper, "Lähra om Begynnelsen" [Teaching on the beginning] (1718) was allegedly translated by Josias Cederhielm ${ }^{24}$ who was one of the Swedish prisoners of war in Russia after the inglorious end of Sweden's imperial ambitions in the Great Northern War. He stayed most of the time in Moscow where he was busy organizing help for the prisoners.

The Uppsala copy of this translation contains a manuscript note on the back of the fly-leaf reading in translation: "Bought in Siberia in 1721 for 12 öre in silver, bound at Jönköping for 24 öre in silver on 26 March $1725 .{ }^{25}$ This, at least, goes well in line with the translator residing in Russia.

The Skokloster copy of "Kort Föreställning" [Short demonstration] (1724) carries, according to the Swedish union catalogue, a manuscript note suggesting that it had been bought at Reval at the end of the same year. ${ }^{26}$

One of the Uppsala copies of "Samtelige Theologiæ Professorum ... RESPONSUM" [Responsum by all theology professors] (1723) carries a name in ink on the title-page, "Johannes Wijk Pettersson," but as this name is fairly common and the note is not dated, the person carrying it is difficult to identify. The name "Anders Lindberg" on the Tallinn copy of the same book is of even less help, as the name is just as common and was, in addition, probably first written around 1800 . Manuscript notes in some other copies of the tracts did not provide any clues as to where the books were read.

Philipp Jacob Spener's “Det Andeliga Presterskapet” [The spiritual priesthood] (1722; no. 6b) is unusual in that it carries a list of errata at the end. This suggests that the man seeing it through the press was not living at Reval. ${ }^{27}$ An errata sheet was also added to the spurious "Oförgripeligit Betenckande Angående ett Öfer=CONSISTORII inrättande" [Humble opinion on establishing a supreme consistory] (1730) as will be discussed below.

\footnotetext{
24 The translator is not indicated in the book itself. Leonard Bygdén, Svenskt anonym- och pseudonymlexikon. Bibliografisk förteckning öfver uppdagade anonymer och pseudonymer $i$ den svenska litteraturen. Faksimilutgåva av originalupplagan [1898-1915] med rättelser och tillägg samt person- och pseudonymregister (Stockholm: Rediviva, 1974), vol. 1, 932; G[unnar] Carlquist, "Josias Cederhielm," Svenskt biografiskt lexikon, 8 (Stockholm: Albert Bonnier, 1929), 14-36, (25); Nordstrandh, Den äldre svenska pietismens litteratur, 84 , all mention Cederhielm as translator without giving any reason for this. Wrangel, Frihetstidens odlingshistoria, 52, calls him editor without providing any explanation.

25 "Kiöpt i Siberien åhr 1721. för 12 [öre] Smt, ombunden i Jön=Kiöping för 24 [öre] Smt a ${ }^{\circ} .1725$ d[en] 26 martij”.

$26<$ http://libris.kb.se/bib/2394906?vw=full> [accessed 25 February 2013]: "Kostar inbunden Dr 6:18 koppmtt. Reuall d. 14 Decembr Ao 1724 ..."

${ }_{27}$ Cf. Jürgen Beyer, "Errata und Korrigenda," Wolfenbütteler Notizen zur Buchgeschichte, 37 (2012), 27-39 (29).
} 
The random evidence assembled here suggests that at least some of the Reval tracts did not find their translators, editors and first readers in Sweden and Finland but rather in Estonia and among the Swedish prisoners of war in Russia, at the time undergoing a well-known pietist awakening. Reval was the obvious place to print books in Swedish for inhabitants of the Russian Empire, even for its involuntary inhabitants. Most of the Swedish prisoners of war, however, could return home in $1722 .{ }^{28}$ Archival records from Reval and letters by Swedish prisoners of war might provide further clues in these matters. ${ }^{29}$ It appears likely, however, that Reval tracts to some extent did reach the Swedish market. ${ }^{30}$

\section{The attribution of books to Reval printshops}

In 2000, Aarma devoted an article to the Reval tracts. ${ }^{31}$ Anyone acquainted with research on the cultural history of early modern Estland and Livland will know that this author has a unique ability to dig up new and exciting sources and to mix up their content. ${ }^{32}$ When we read in her article that the first pietist tract in Swedish was probably not printed at Reval in 1718 but already in $1708,{ }^{33}$ this might be an important new piece of information, but

28 Cf. Adam Lewenhaupt, Karl XII:s officerare: biografiska anteckningar, 2 vols. (Stockholm: P. A. Norstedt \& Söner, 1920-1921).

29 Karolinska krigares dagböcker [as of vol. 3 with the addition: jämte andra samtida skrifter], 12 vols., [ed. by August Quennerstedt] (Lund: Gleerupska univ. bokhandeln, 1901-1918), however, did not provide any leads.

30 Prästeståndets riksdagsprotokoll, vol. 7, 527. Nordstrandh, Den äldre svenska pietismens litteratur, 21, summarizes a 1722 meeting of the Stockholm consistory in which the title of two Reval tracts are mentioned. A closer inspection, however, reveals that these editions were not printed at Reval (cf. ibid., XLIII-XLIV, 88-91, 102-103 and especially the facsimiles on pp. 90, 101).

31 Aarma, "Rääveli traktaadid."

32 Cf. Jürgen Beyer, "[review article, partly on Aarma, Põhja-Eesti vaimulike lühielulood]," Zeitschrift für Ostmitteleuropa-Forschung 56 (2007): 618-621; Aivar Põldvee, "”Lihtsate eestlaste ebausukombed" ja Johann Wolfgang Boecleri tagasitulek. Lisandusi kiriku, kirjanduse ja kommete ajaloole," Ajalookirjutaja aeg / Aetas historicorum, ed. by Piret Lotman (Tallinn: Eesti Rahvusraamatukogu, 2008), 141-227 (145, 148, 175); id., "Rektor ja pastor Johannes Forselius. Märkmeid eluloost, argielust ja pedagoogikast," Läänemere provintside arenguperspektiivid Rootsi suurriigis 16/17. sajandil, 3, ed. by Enn Küng [and Kai Tafenau] (Tartu: Eesti Ajalooarhiiv, 2009), 231-279 (234, 238, 241-242, 248, 252, 258, 260); id., Bengt Gottfried Forselius ja rahvahariduse lätted Eesti- ja Liivimaal (diss. Tartu) (Tartu: Tartu Ülikooli Kirjastus, 2010), 44-46; Jürgen Beyer, "Anforderungen an Pastorenbücher," Zeitschrift für Ostmitteleuropa-Forschung, 59 (2010): 258-261.

33 Aarma, "Rääveli traktaadid," 70. On p. 71 she repeats this information as a fact. 
it might just as well be an error. The same applies to her dating the end of the series to $1730,{ }^{34}$ not to 1726 .

I therefore decided to submit the tracts of 1708 and 1730 to closer scrutiny. First the book of 1708. It runs over thirty pages and contains the already mentioned opinion by Neumann on gatherings of Silesian children preaching in the open air, translated from German to Swedish. ${ }^{35}$ There seems to be only one extant copy, held by the Royal Library in Stockholm. The pamphlet itself carries no indication of printer, place or year of publication, but the Royal Library is convinced that it was produced in 1708. This information has even been added to the spine of the binding. A pencil note on the back of the fly-leaf states that the book was printed at Reval, an information also transmitted via the library's catalogue to the Swedish union catalogue, LIBRIS. ${ }^{36}$

Furthermore, there exists another version of the Swedish text, printed in 1708 in Stockholm. ${ }^{37}$ This suggests some questions. If we are dealing with a Reval tract as they are commonly perceived, i. e. a clandestine pietist book not to be allowed into the Swedish realm, this does not square with the same text being printed so-to-say under the eyes of the central administration in Stockholm. Additionally, in 1708 censorship rules were still essentially the same at Reval and in Stockholm. ${ }^{38}$ It was first after the Russian conquest of Estland and Livland in 1710 that the new authorities did not bother so terribly much about whether books printed in the Baltic provinces conformed to the highest standards of Lutheran orthodoxy.

Finally, all the later Reval tracts were printed by Köhler, but in 1708 the Reval printshop was still run by Christoph Brendeken who died of the

34 Aarma, "Raaveli traktaadid," 71.

35 Two German versions are available: Caspar Neumann, Unvorgreifliches GUTALHTEN [sic] Uber die in Schlesien offentlich Bethende Kinder / Welches In der Furcht des HErren abgefasset / Und den 29sten Februar. An: 1708. In der damaligen Abend=Predigt seiner Gemeinde fürgetragen (Breslau: n. pr., 1708); Gründliche Nachricht Von derer Evangelischen Schlesier Kinder=Andacht / Oder Denen [sic] / von denen Kindern in Schlesien / unter freyen [sic] Himmel / auf offenen [sic] Felde haltenden Bet=Stunden. Nebst Hn. Caspar Neumanns / Inspectoris bey der Evangelischen Kirche / und Schule zu St. Elisabeth / in Breßlau / und anderer führenden Gutachten / über solches Beten derer Kinder (n. pl.: n. pr., 1708).

$36<$ http://libris.kb.se> [accessed 6 October 2013].

37 Grundelig Underrättelse Om de Evangeliske Schlesiske Barnens Andakt / Eller Deras under bar Himmel och på öpna fältet hållne Böne=Stunder. Tillika med Herr Mag. CASPAR NEUMANS Betänkiande däröfwer (Stockholm: Johan Henr. Werner, 1708).

38 Admittedly, in 1683 another of Neumann's books was forbidden in Sweden, but that had nothing to do with pietism or alleged heresy. In this case, the printer had infringed on another printer's privilege (Bengt Åhlén, Agneta Åhlén [and Lillemor Widgren Matlack], Censur och tryckfrihet. Farliga skrifter i Sverige 1522-1954 (Södertälje: Fingraf, 2002), no. 16.99). 
plague in 1710 . He was followed by his widow and his son, Johann Christoph Brendeken, who passed away already in $1716 .^{39}$ Then Köhler took over. He had printed at Narva from 1696 to 1703 and left for Moscow in 1705, but it is not known what he did there. ${ }^{40}$ If the pietist imprints in Swedish were a specialty of Köhler, a book of 1708 should not be attributed to him. However, it is conceivable that the book was, indeed, printed at Reval though not in 1708 but ten to fifteen years later, together with the well-known Reval tracts. After all, the year 1708 has been added to the spine of the Stockholm copy by the Royal Library. It is not to be found in the book itself.

\section{Comparison of watermarks}

The watermark evidence turned out to be inconclusive. As the books were printed in $-8^{\circ}$ or in $-12^{\circ}$, only fractions of the watermark could be discerned on a few leaves. It would not have been unusual if Köhler used different paper for books printed in different years. Only the comparison with a large number of books printed simultaneously elsewhere might suggest that a certain title was not printed by Köhler but rather by another printshop using the same paper during that year. In the time span available for writing this essay it was not possible to conduct research on such a grand scale. However, so much can be stated that the title pages of the Uppsala copies of "Samtelige Theologiæ Professorum ... RESPONSUM," "Menniskors Lefnads=Tid" [The life-time of Man], "Kort Underrättelse" [Short information], "En Sann och Falsk Christen" [A true and a false Christian], "En Syndares Elände och Tröst" [The misery and consolation of a sinner], "Det Nya Creaturet" [The new creature] and "Ett Rättsinnigt Wäsende" [Truthfulness], all dated to 1723 and gathered in one volume, were printed on the same paper.

The watermarks of the alleged Reval imprint of 1708 did not show any resemblance to the watermarks in the attested Reval imprints produced 1718 or later, but that alone obviously would not exclude that the book may have been printed at Reval.

39 Deutschbaltisches biographisches Lexikon 1710-1960, ed. by Wilhelm Lenz et al. (Cologne \& Vienna: Böhlau, 1970), 100.

40 Enn Küng, "Johann Köhler ja Narva trükikoda 1695-1705," Läänemere provintside arenguperspektiivid rootsi suurriigis 16./17. sajandil, 2, ed. by id. (Tartu: Eesti Ajalooarhiiv, 2006), 336-362, with a bibliography of Köhler's Narva production on pp. 352-356. Some additional titles in the online Estonian retrospective national bibliography $<$ http:// tallinn.ester.ee> [accessed 6 October 2013]. 


\section{Comparison of typography}

Almost all Swedish books with "Reval: Johan(n) Köhler" on the title page carry a decorative line above the imprint, but otherwise they contain only very few ornaments. The decorative line is lacking in the alleged Reval book of 1708. One might, of course, argue that it is not needed if no name of the printer has to be separated from the title. The decorative line is also lacking in three other imprints, referring to the Swedish Diet held in 1720. They neither indicate the place nor the year of publication ("En Rättskaffens Biskops Swar" [Answer by a worthy bishop], "Är det Christeligit” [Is it Christian] and "Kort Extract" [Short extract]). These titles, however, are unlikely to have been printed by Köhler, judging from the shape of the letter $\stackrel{{ }^{41}}{{ }^{41}}$ However, these three tracts seem to have been produced by the same printer. The decorative line is also absent in "L'Esprit egaré du Monde" (1724), carrying a Köhler imprint, but this tract uses a different design for the title page altogether: the text is spread out over the entire opening. The decorative line is also lacking in a late Köhler imprint, "De Trognas Delachtighet i JEsu Christo" [The faithfuls' fellowship in Jesus Christ] (1725), while "Helgonens Grönskande Ben" [The viridescent bones of saints] (1726) sports another kind of decorative line. The first imprint, "Lähra om Begynnelsen" [Teaching on the beginning] (1718) carries yet another decorative line.

A certain flower ornament can be found in four books mentioning Köhler on the title page, but not in any of the spurious ones ("Kort Underrättelse" (1723); "Ett Rättsinnigt Wäsende" (1723); "Kort Föreställning" (1724); "De Trognas Delachtighet i JEsu Christo" (1725)).

In almost all Reval tracts with "Reval" set out on the title page, the text starts on the back of the title page, at least with a dedication, ${ }^{42}$ while in the alleged imprint of 1708 the back of the title page is left blank. The imprint of 1708 is furthermore lacking the pagination otherwise to be found in the Reval tracts in a rather uniform way. ${ }^{43}$

Whereas Köhler in his Swedish books frequently varies the typeface, the alleged 1708 book is typographically remarkably uniform: Only a bold

41 Aarma, "Rääveli traktaadid," 71 and 74 , note 26 , is firmly convinced that the three small books were printed at Reval in 1720 and does not indicate that this information cannot be found in the books themselves. Apparently she did not see the originals but only the catalogue posts in LIBRIS, as a comparison of the renderings of the title pages gives at hand.

${ }_{42}$ Not in Helgonens Grönskande Ben (1726).

43 Exceptions: Spener, Det Andeliga Presterskapet (1722); Helgonens Grönskande Ben (1726). 
and somewhat larger typeface is used for emphasis, and a smaller one for marginal notes. The body type is somewhat larger than in other books of the period and in books known to have been printed by Köhler. Unusually, this book uses gothic type for biblical references in the margin, even though they are in Latin. In most of his other books, Köhler prints such references in Latin type. ${ }^{44}$

While these layout features provide indications for not attributing the 1708 imprint to Köhler, they are, admittedly, not entirely conclusive. Comparing, however, the body type of the alleged 1708 book with Köhler's other production in Swedish, it is clear that the typeface of the 1708 imprint cannot be found in the other books. Neither could the typeface be found in some randomly selected books printed by Köhler in German and Estonian. ${ }^{45}$ (Books in Latin, also produced by Köhler, would not use gothic type and would thus not be of help in comparisons.) I therefore have no hesitation whatsoever to state that the 1708 translation of Neumann cannot have been printed by Köhler at Reval after his return from Russia, nor was it printed at Reval by Brendeken before Köhler arrived in town. ${ }^{46}$

The examination of the alleged Reval imprint of 1730, "Oförgripeligit Betenckande Angående ett Öfer=CONSISTORII inrättande" [Humble opinion on establishing a supreme consistory], came to a similar result which for lack of space cannot be discussed in detail here. This book was not printed at Reval either. However, most likely it was neither printed in Sweden nor Finland, as can be deduced from the errata sheet. The mistakes corrected (for instance, $\ddot{a}$ instead of $a, i j$ in place of $y$ ) suggest that the book was produced by a printer not mastering the Swedish language. ${ }^{47}$ Two mistakes, duly corrected in the errata sheet, are even to be found on the title page!

\footnotetext{
44 Not in De Trognas Delachtighet (1725).

45 Georg Günther Tuntzelmann, Die Seligkeit der Gerechten nach dem Tode / bey dem ... Leichen=Begängnis Des ... Christian Buchau ... (Reval: Johan Köhler, [1721]); Der Käyserl: Stadt REVAL Wäisen=Gerichts und Vormünder=Ordnung ... ([Reval:] Johann Köhler, 1722); Eesti=Ma Rahwa Koddo= ning Kirko=Ramat ... (Reval: Joan Köler, ${ }^{2} 1728$ ). 46 Cf. the typefaces of Förordning och REGLEMENTE för INFANTERIET ... (Reval: Christoph Brendeken, 1701); Neu=vermehrtes REVALISCHES Gesang=Buch ... (Reval: Christ. Brendeken, 1704); Meie Issanda JEsusse Kristusse Uus Testament ... (Reval: Johan Kristow Prendeken, 1715).

47 For similar mistakes in inscriptions, cf. Jürgen Beyer, "Den så kallade stenmästargravstenen från 1570-talet i Vamlingbo kyrka på Gotland. Text, tolkning och bakgrund," Fornvännen. Journal of Swedish Antiquarian Research, 106 (2011), 113-126 (119-121); id., "Stiftung, Plazierung und Funktion von Wand- und Kronleuchtern in lutherischen Kirchen,” Zeitschrift für Lübeckische Geschichte, 92 (2012), 101-150 (106-110).
} 
It is not the object of this essay to trace the true printers of the five spurious Reval tracts. This would probably not be as difficult as in the case of German, Dutch or English publications. As the books' typefaces contain the letter $a$ in a design in line with the other letters, it is likely that they - except for the book of 1730 just mentioned - were printed somewhere in Sweden, Finland or the Swedish possessions in northern Germany, since the letter $\stackrel{a}{ }$ was not used elsewhere at the time. Uppsala University Library, Lund University Library and the Stockholm Royal Library all contain almost complete holdings of Swedish books from this period, therefore it would be possible to find out where the same typefaces were used. In contrast to the early days of printing, however, printshops of the early eighteenth century bought their typefaces from specialized type foundries, and therefore such very time-consuming research would most likely result in pointing out several printshops using the same typefaces which would only marginally bring us closer to the true printer of the book. Ornaments, indeed, would lend themselves better for attributing books to a certain printer, as they showed greater variation, but the spurious Reval tracts unfortunately (and possibly for this very reason) contain only very few of them.

Interestingly, a number of the Reval tracts were reprinted, quite legally, in Stockholm in $1760 .{ }^{48}$ The editor informs us in the preface that the new edition was approved by the Stockholm consistory and that everything theologically doubtful in the originals had been amended. With eight texts, this reprint edition contains only about half of what scholars have considered to make up the Reval tracts. These eight tracts were originally, indeed, printed at Reval, all with the place of publication and the printer clearly set out on the title-pages.

As book historians familiar with the output of the famous Pierre Marteau or Pieter Hamer, allegedly of Cologne,$^{49}$ know all too well, complete imprints do not necessarily indicate that the data provided are correct. It can therefore not be excluded that Köhler's name was used by some virtual publisher, but a number of his imprints, not least the German and Estonian ones, seem to be sure enough.

48 Några Små Traktater Til Enfaldigas Hjelpreda Under deras Wägledande, Ifrån det usla Jordiska, Til det Sälla Himmelska. För detta På Swenska Språket tryckte i Revel, men nu å nyo medelst några wälmentas bekostnad uplagde, [ed. by Peter Murbeck] (Stockholm: Nyström och Stolpe, 1760).

${ }_{49}$ Cf. $<$ http://www.pierre-marteau.com $>$ [accessed 6 October 2013]. 


\section{Origin of the attributions}

As we have seen, not only the book of 1708 was wrongly attributed to a Reval printer, also the publication of 1730 suffered this fate as did three tracts referring to the Swedish Diet held in 1720 .

How should we explain this proliferation of attributions to the Reval printshop? Interestingly, the Swedish union catalogue LIBRIS, when stating that these books were printed at Reval, in most cases does not mention the printer. This suggests that the attributions are fairly old, dating back to a time when Swedish library catalogues would only indicate the place of publication but not the publisher or the printer. Until the end of the eighteenth century, however, Reval only housed one printer simultaneously, ${ }^{50}$ and indicating this place of publication, therefore, attributes the imprint automatically to a certain printer.

I think the mechanism behind these attributions was the following: Librarians and scholars - such as Carl Gustaf Warmholtz two hundred years $\mathrm{ago}^{51}$ - knew that there had been a Reval series of pietist books in Swedish, and whenever they found a Swedish book of that ilk not indicating where it had been printed, they located it to Reval. Later librarians and scholars then went on to build castles in the air on this basis. The alleged clandestine character of these books seems to have been contagious. The contagion, however, did not spread directly from book to book but resulted much rather from the associative thinking of learned but uncritical librarians and scholars.

Ever since the notion of "rare books" was coined in the eighteenth century, publications suppressed by the authorities have captivated the imagination of scholars, book collectors and librarians. ${ }^{52}$ Since there was a demand for suppressed books from the past, the antiquarian book market

50 Endel Annus, "Boktryckerierna i Estland 1631-1900," Den estniska boken genom seklerna. Bokhistoriska uppsatser, ed. by id. and Esko Häkli (Helsinki: Helsingfors Universitetsbibliotek, 1995), 190-191.

${ }^{51}$ Carl Gust[af] Warmholtz, BIBLIOTHECA HISTORICA SUEO-GOTHICA; Eller FÖRTECKNING Uppå ... Böcker ... om Svenska Historien ..., 15 vols. (Stockholm [etc.]: Anders Jac. Nordström [et al.], 1782-1817).

52 Cf. [Jacob Friedrich Reimmann,] BIBLIOTHECA HISTORIÆ LITERARIÆ Critica, eaque Generalis, hoc est CATALOGI BIBLIOTHECA REIMMANNIANÆ SystematicoCritica TOMVS SECVNDVS ... (Hildesheim: Vidua Lud. Schroederi, 1739), 103: "Omnes libri impressi rari sunt, qvi excusi sunt ab inventione Artis typographicæ usqve ad A. C. 1500. Item qvi auctoritate publica prohibiti, combusti, expurgati, castrati. Qui cum aliis collati, ab ipsis Auctoribus, vel etiam ab alio erudito Viro notati, correcti, aucti, additametis [sic] qvibusdam ineditis locupletati, singulares ob causas suppressi, $\pi \alpha \rho \alpha \delta$ o $\xi_{o l .}$ Qvorum oppido pauca excusa sunt exemplaria. Qvi prodierunt sumtibus Auctorum, in locis dissitis: Lusitania, Hispania, Italia, Svecia, Russia \&c." 
responded by attributing books to printers of clandestine literature and by assuming that the books had been suppressed. Ironically, suppressed books are therefore much more likely to be preserved to our days than books the authorities considered to be suitable for distribution. The survival rate of catechisms and primers, for instance, is notoriously poor.

Attributions of books to printers, places of publication or authors tend to be copied from earlier works and catalogues into newer catalogues without checking the plausibility of the attribution. To mention a recent Swedish example, Bengt Åhlén's bibliography of "dangerous" books in Sweden lists all Reval tracts - except nos. (1) and (7) - simply on the grounds that they were discussed by Nordstrandh in his study of Swedish pietist literature, but as the compilers admit, not all books in the bibliography were actually forbidden. ${ }^{53}$ With the advent of electronic union catalogues this process has greatly accelerated. It is high time for scholars and cataloguers to pause and to assess the quality of the existing attributions before the errors are allowed to spread even further.

While it was easy to disprove the attributions in the Reval case with only one printshop allegedly involved, a similar mechanism could probably be discerned in attributions to more busy places of clandestine publishing such as Altona and, above all, Amsterdam. Amsterdam certainly did account for large amounts of heterodox literature published during the early modern period, but were all books attributed to Amsterdam printers really produced in that city? The findings by Emil Weller on false imprints have been repeated time and again for one and a half centuries now, even though he did not indicate how he had arrived at his conclusions. ${ }^{54} \mathrm{VD} 17$ cites him - to give just one example for Weller's continuing vitality - more than 700 times as an authority. ${ }^{55}$

Convincing attributions can be based on a vast array of sources such as correspondence by authors and printers, archival records, authors' printed lists of their own publications or, as in this essay, typographical evidence. ${ }^{56}$

\footnotetext{
53 Åhlén, Åhlén and Widgren Matlack, Censur och tryckfrihet, 9; cf. also Bengt Åhlén, Ord mot ordningen: farliga skrifter, bokbål och kättarprocesser i svensk censurhistoria, ed. by Agneta Åhlén, Lillemor Widgren Matlack and Christer Hellmark (Stockholm: Ordfront, 1986), 78-79.

54 Emil Weller, Die falschen und fingirten Druckorte: Repertorium der seit Erfindung der Buchdruckerkunst unter falscher Firma erschienenen deutschen, lateinischen und französischen Schriften, 2 vols. (Leipzig: Wilhelm Engelman, ${ }^{2} 1864$ ).

${ }_{55}$ Das Verzeichnis der im deutschen Sprachraum erschienenen Drucke des 17. Jahrhunderts, $<$ http://www.vd17.de> [accessed 6 October 2013].

56 Cf. Jan Drees, Deutschsprachige Gelegenheitsdichtung in Stockholm und Uppsala zwischen 1613 und 1719. Bibliographie der Drucke nebst einem Inventar der in ihnen
} 
While catalogues and databases of ornaments might be of help in the case of more richly decorated books, comparing typographical peculiarities or watermarks will remain dependent on the availability of large amounts of the period's books for easy inspection on the same table. In many libraries - and the Stockholm Royal Library, alas, is one of the more frightening examples - current reading room policies unfortunately prevent this kind of research. ${ }^{57}$ By allowing scholars to pursue their bibliographical research unhampered, libraries would, indeed, contribute to a critical reassessment of their catalogue data. This should be a prime concern for scholarly libraries.

JÜRGEN BEYER (b. 1965) is a Senior Research Fellow at the Research Centre of Tartu University Library.*

verwendeten dekorativen Druckstöcke (Stockholm: [Kungl. biblioteket], 1995); Anna Perälä, Suomen typografinen atlas, 2 vols. (Helsinki: Helsingin yliopiston kirjasto, 20oo); Paul Dijstelberge, De beer is los! Ursicula: een database van typografisch materiaal uit het eerste kwart van de zeventiende eeuw als instrument voor het identificeren van drukken (unpublished Ph.D. thesis Amsterdam, 2007); Jürgen Beyer and Leigh T. I. Penman, "Printed autobibliographies from the sixteenth and seventeenth centuries," Documenting the early modern book world: inventories and catalogues in manuscript and print, ed. by Malcolm Walsby and Natasha Constantinidou (Leyden \& Boston: Brill, 2013), 161-184; Christoph Boveland and Gundula Boveland, "Der Bär im Akanthus. Beobachtungen an einer Schlussvignette," "Willst du dich am Ganzen erquicken, So mußt du das Ganze im Kleinsten erblicken" (Goethe): studies on the German book presented to Ulrich Kopp in his retirement, ed. by William A. Kelly and Jürgen Beyer (Tartu: University of Tartu Press, forthcoming); Leigh T. I. Penman, "A heterodox publishing enterprise of the Thirty Years' War: the Amsterdam office of Hans Fabel (1616 - after 1650)," The Library, 15 (2014) (forthcoming).

57 Cf. Jürgen Beyer, "The influence of reading room rules on the quality and efficiency of historical research," Text. Svensk tidskrift för bibliografi / Swedish Journal of Bibliography, 8:3 (2014) (forthcoming).

* Correspondence: Tartu University Library, W. Struve 1, 50091 Tartu, Estonia. E-mail: Jurgen.Beyer@ut.ee 


\section{BIBLIOGRAPHY of the Reval tracts, genuine and spurious}

$\begin{array}{ll}\text { List }^{\text {of }} \text { libraries }^{58} \\ \text { C } & \text { Copenhagen Royal Library } \\ \text { H } & \text { Helsinki National Library } \\ \text { K } & \text { Kalmar Municipal Library } \\ \text { L } & \text { Lund University Library } \\ \text { Li } & \text { Linköping Municipal Library } \\ \text { Ln } & \text { London British Library } \\ \text { N } & \text { Norrköping Municipal Library }{ }^{59} \\ \text { Ö } & \text { Östersund Regional Library } \\ \text { S } & \text { Stockholm Royal Library } \\ \text { Sko } & \text { Skokloster Castle } \\ \text { T } & \text { Tallinn Academic Library } \\ \text { U } & \text { Uppsala University Library } \\ \text { V } & \text { Västerås Municipal Library }\end{array}$

Signs

* Copy not inspected; information on the copy taken, for instance, from online catalogues $\dagger$ Spurious

$\dagger$ (1) Casparus Neumannus, Oförgripelige Betänckiande Öfwer de i Schlesien offentligen Bedjande Barnen / Hwilket Af honom i HErrans fruchtan är samman fattat / och den 29 Februarij 1708. Uthi den dåwarande Afton=Predikan sine Åhörare förestält; Men af Tyskan efter någras begiäran på Swenska Tungomålet öfwersatt Af JOH. WITTE (n. pl.: n. pr., n. d.).

$8^{\circ}, 30$ pp. S. ${ }^{60}$

Printed at Reval in 1708 according to LIBRIS.

(2) [August Hermann Francke,] Lähra om Begynnelsen till ett Christeligit Lefwerne / Nembligen: I. Grundelig Anledning till sann Boot och Troo på GUD. II. Enfaldig Underrättelse, huru man skall läsa den Heliga Skrift till sin sanna Upbyggelse. III. Anwisning / huru man retteligen / effter Skriftenes innehåld och GUDZ wählbehag skall bedia. [I]V. Bepröfwande / om man hafwer den sanna lefwande Troon på CHristum / eller intet. Utur Tyska Språket

\footnotetext{
58 In case a library holds more than one copy, the code for the library is repeated. In Stockholm, at least, the actual number of copies often seems to be larger than the catalogue indicates.

${ }^{59}$ All Norrköping books listed below are found in the Finspong collection, acquired by the library from a manor house a hundred years ago. The fact that the books are now housed at Norrköping led Aarma, "Rääveli traktaadid," 69, to believe that they were brought to town by Reiner Broocman, formerly of Lais/Laiuse (Livland) and pastor in Norrköping since 1712 ! On Broocman, cf. Tering, Lexikon estländischer, livländischer und kurländischer Studenten.

60 Manuscript notes in Swedish at the end.
} 
öfwersatt ..., [allegedly translated by Josias Cederhielm,] (REVAL: Johann Köhler, 1718).

$12^{\circ},[154]$ pp. U. ${ }^{61}$

† (3) [Nils von Lang,] En Rättskaffens Biskops Swar Till sin SON / Som begärt / det Fadren wille Förskaffa Honom och Hans Syskon Adeligit Stånd och Skiölde=Bref / Allmänt kunnigt blifwit under påstående Riksdag i Stockholm 1720. (n. pl.: n. pr., n. d.).

$8^{\circ}, 39$ pp. $\mathbf{L}^{*}, \mathbf{N}^{\star}, \mathbf{S}^{*}, \mathbf{S}^{*}, \mathbf{U}^{62}$

"Believed to be printed at Reval" according to Warmholtz ${ }^{63}$; printed at Reval in 1720 as stated in LIBRIS.

† (4) [Nils von Lang,] Är det Christeligit och med Wår Evangeliska Lära enigt I at Högwördige Presterskapet söka rum och Säte på Det Werldsliga Ståndets Rang=Ordning? Under påstående riksdag 1720 (n. pl.: n. pr., n. d.). $8^{\circ}, 32$ pp. $\mathbf{L}^{*}, \mathbf{N}^{\star}, \mathbf{S}, \mathbf{S}^{\star}, \mathbf{U}$.

"Believed to be printed at Reval" according to Warmholtz ${ }^{64}$; printed at Reval in 1720 as stated in LIBRIS.

$\dagger$ (5) [Nils von Lang,] Kort Extract Utaf Samtelige Högl. Ständernas Urgamla Evangeliska Privilegier / Af Den dyra Guds Mannen LVTHERO fordom ur Guds Heliga Ord författade, och Sedermera af andra rättsinte hans effterföljare altid förswarade emot det farliga Påfwiske Enwäldet oppifwit [sic] under påstående Riksdag i Stockholm 1720. (n. pl.: n. pr., n. d.).

$8^{\circ}, 20$ pp. $\mathbf{L}^{\star}, \mathbf{N}^{*}, \mathbf{S}, \mathbf{S}^{\star}, \mathbf{U} \cdot{ }^{65}$

Printed at Reval in 1720 according to LIBRIS.

(6a) [Philipp Jacob Spener,] Det Andeliga Presterskapet af GUDz Heliga Ord korteligen beskrifwit och med Gudelige Lärares instämmande Witnesbörder bekräftadt (n. pl.: n. pr., 1722). $12^{\circ}$, [8], [109] pp. Li $\mathbf{i}^{*}, \mathbf{S}$.

Printed at Reval by J. Köhler according to LIBRIS.

(6b) Philip. Jacob Spener, Det Andeliga Presterskapet / af GUDz Heliga Ord korteligen beskrifwit / och med Gudelige Lärares instämmande Witnesbörder

${ }_{61}$ Cf. n. 27 for a manuscript note on the back of the fly-leaf.

62 A number of printing errors have been corrected by hand.

63 Warmholtz, Bibliotheca historica, vol. 4, no. 2444: "Desse Skrifter tros vara tryckte i Reval".

64 Warmholtz, Bibliotheca historica, vol. 4, no. 2445: "Desse Skrifter tros vara tryckte i Reval".

65 A number of printing errors have been corrected by hand. 
bekräftadt: Först i Tyskan sammanskrifwit af Doct. Philip. Jacob Spener; men nu sedermehra / för des stora nytta skull / til märckelig Upbyggelse i Christendomen / på Swenska öfwersatt (Reval: Joh: Köhler, 1722).

$12^{\circ},[8], 106 \mathrm{pp} . \mathbf{N}^{\star}, \mathbf{S}, \mathbf{S}^{\star}, \mathbf{U}$.

Apart from the titlepage, (6a) and (6b) differ only in the last signature (pp. 97ff.).

(7) Samtelige Theologioe Professorum i Leipzig Åhr 1710. Utfärdade Christeliga och Wälgrundade RESPONSUM eller Swar på En hos them inkommen Förfrågning Om Thet så kallade PIETISTERIE. Förswänskat åhr 1722. (REVAL: Johann Köhler, 1723).

$8^{\circ}, 14$ pp. $\mathbf{L}^{\star}, \mathbf{L}^{\star}, \mathbf{L} \mathbf{n}^{\star}, \mathbf{N}^{\star}, \mathbf{S}, \mathbf{T},{ }^{66} \mathbf{U}, \mathbf{U} .{ }^{67}$

(8) [August Hermann Francke,] Menniskors Lefnads=Tid betrachtad och förestäld såsom En Sädes=and / I anledning af Galat: 6/ w. 7. 8. (REVAL: Johann Köhler, 1723).

$8^{\circ}, 47$ pp. $\mathbf{H}^{\star}, \mathbf{H}^{\star}, \mathbf{L}^{\star}, \mathbf{L i}^{*}, \mathbf{L i}^{\star}, \mathbf{L} \mathbf{n}^{\star}, \mathbf{S}, \mathbf{T}, \mathbf{U}$.

(9) [August Hermann Francke,] Kort Underrättelse Om Möijeligheten At kunna rätteligen blifwa omwänd til GUD / och komma til en Sann Christendoms Utöfning (REVAL: Johann Köhler, 1723). $8^{\circ}, 63 \mathrm{pp} . \mathbf{H}^{\star}, \mathbf{H}^{\star}, \mathbf{L}^{\star}, \mathbf{L i}^{\star}, \mathbf{L n} \mathbf{n}^{*}, \mathbf{S}, \mathbf{T}, \mathbf{U}, \mathbf{U}$.

(10) Anthon Wilhelm Böhme, En Sann och Falsk Christen / förestäld Uti en Predikan öfwer 2. Tim. 3 / 5. Åhr 1711. ... (REVAL: Johann Köhler, 1723). $8^{\circ}, 48$ pp. $\mathbf{H}^{\star}, \mathbf{L}^{\star}, \mathbf{L}^{\star}, \mathbf{L i}^{\star}, \mathbf{L n}^{\star}, \mathbf{S}, \mathbf{T}, \mathbf{U}$.

(11) Anthon Wilhelm Böhme, En Syndares Elände och Tröst / förestälte Uti en Predikan på Palm=Söndagen Åhr 1718. utur Esai. 66. w. 2. ... (REVAL: Johann Köhler, 1723).

$8^{\circ}, 32$ pp. $\mathbf{H}^{\star}, \mathbf{L}^{\star}, \mathbf{L}^{\star}, \mathbf{L i}^{\star}, \mathbf{L i}^{\star}, \mathbf{L} \mathbf{n}^{\star}, \mathbf{S}, \mathbf{T}, \mathbf{U}$.

(12) Anthon Wilhelm Böhme, Det Nya Creaturet i CHristo JEsu / förestält Uti en Predikan på Ny=Åhrsdagen Åhr 1719. öfwer 2. Cor: 5 / w. 17.... (REVAL: Johann Köhler, 1723). $8^{\circ}, 39$ pp. $\mathbf{H}^{\star}, \mathbf{H}^{\star}, \mathbf{L}^{\star}, \mathbf{L}^{\star}, \mathbf{L}^{\star}, \mathbf{L i}^{*}, \mathbf{L i}^{\star}, \mathbf{L} \mathbf{n}^{\star}, \mathbf{S}, \mathbf{T}, \mathbf{U}$.

66 Owner's name in Latin script, possibly around 1800 , on the titlepage: "Anders Lindberg".

67 Owner's name on the titlepage: “Johannes Wijk Pettersson” (shelfmark: Sv. Teol. Sekt. Kaps. Läseri). 
(13) [August Hermann Francke?,] Ett Rättsinnigt Wäsende i JEsu / (Ephes. 4 / 21.) Förestält Uti Menniskans Fråga och Andans Swar. Samt En kort Bättrings=betrachtelse (REVAL: Johann Köhler, 1723). $8^{\circ},[12], 76$ pp. $\mathbf{L}^{\star}, \mathbf{L}^{\star}, \mathbf{L i}^{\star}, \mathbf{L i}^{\star}, \mathbf{L} \mathbf{n}^{\star}, \mathbf{S}, \mathbf{T}, \mathbf{U}^{\star},{ }^{68} \mathbf{U}$.

(14) [Otto Heinrich Becker,] L'Esprit egaré [sic] du Monde, Thet är / Werldenes Wrångwisa Omdöme om Andelige Saker / eller En wälment Påminnelse och Underrättelse / emot the werldsligen=sinnade Menniskors förutfattade Onda och Wrångwisa meningar och Lättsinnige Omdömen / The ther utan skälig orsak / allenast af en blind Ifwer för Religionen, söka at föra sin Nästa hos andra i mißtankar för wilfarande lära ... På Tyska uplagt i Amsterdam åhr 1710. och nu på Swenskan öfwersatt / samt til Trycket befordrat af Axel Julius Herlin / Kyrckioherde wid St. Jacobi Försambling uti Estland (REVAL: Johan Köhler, 1724).

$8^{\circ}, 94$ pp. $\mathbf{H}^{*}, \mathbf{H}^{*}, \mathbf{L}^{*}, \mathbf{L}^{*}, \mathbf{L i}^{*}, \mathbf{L i}^{*}, \mathbf{N}^{*}, \mathbf{S}, \mathbf{U}^{69}$

(15) Olaus Verelius, Kort Föreställning Om Kyrko=Styrelsen / Hwilken Fordom Professoren ... Olaus Verelius författat på Latin, Och Herr Andreas Goding ... Jemte Ett litet Företal / Genom trycket i dagsliuset befordrat Åhr 1722. Jemwäl samma Åhr på Swenska öfwersatt blifwit (REVAL: Johan Köhler, 1724). $8^{\circ}, 45$ pp. C, $\mathbf{H}^{*}, \mathbf{H}^{\star}, \mathbf{L}^{\star}, \mathbf{L i}^{*}, \mathbf{N}^{*}, \mathbf{O}^{*}, \mathbf{S}, \mathbf{S k o} \mathbf{H}^{\star}, \mathbf{U}, \mathbf{V}^{\star}$.

(16) [Jonas Tellmann,] ${ }^{70}$ De Trognas Delachtighet i JEsu CHristo / (1 Cor. 1 / 9.) bestående uti Nytta och Tröst til Trones Styrkio / samt Lärdom och Plicht til Lefwernets Förbättring: Alt ifrån JESU Namn in til Hans yttersta Ankomst til Domen; Förestäld Uti Frågor och Swar / med Andans egne ord utsökte af den Heliga Skrift / samt deröfwer stälte Böner (REVAL: Johan Köhler, 1725). $8^{\circ},[125]$ pp. $\mathbf{H}^{\star}, \mathbf{L}^{\star}, \mathbf{N}^{\star}, \mathbf{S}, \mathbf{U}, \mathbf{U}$ [incomplete].

(17) Några Wälmente och på GUdz ord sig grundande Påminnelser Angående Christendomens Förbättring / För Etthundrade Åhr sedan på Tyska skrefne / och sedermera på Swenska öfwersatte; Samt nu för deras stora Nyttighet

68 Åhlén, Åhlén and Widgren Matlack, Censur och tryckfrihet, no. 17.13, state that a copy is to be found in the Åhlén collection of Uppsala University Library. That is not now the case and probably never was, as librarian Håkan Hallberg kindly informed me on 10 October 2013.

69 In this copy the sequence of leaves in signature E (pp. 63-78) is wrong, but all pages are extant.

70 Author according to Nordstrandh, Den äldre svenska pietismens litteratur, 221, who also mentions that a copy in Gothenburg Municipal Library carries the name Johan Bruce on the titlepage. LIBRIS does not indicate an author. 
skull / genom Censur, til Trycket befordrade af Axel Julius Herlin Kyrckioherde wid St. Jacobi Församling uti Ehstland (Reval: Johan Köhler, 1726). ${ }^{71}$ $8^{\circ}, 40$ pp. $\mathbf{H}^{\star}, \mathbf{L}^{\star}, \mathbf{O}^{*}, \mathbf{S}, \mathbf{U}, \mathbf{U} .^{72}$

(18) [Jonas Rothåf,] Helgonens Grönskande Ben uti Grafwen / eller Åtskillige Gudelige och Anderike Sånger / som i Lifstiden Af en förlängst / i HErranom / afsomnad äro sammanskrefne; Men nu mera Ihopsamlade och utur deras tysta giömme / genom Trycket $i$ dagsliuset / utgifne af Deß närmaste Wän på Jorden (REVAL: Johan Köhler, 1726).

$12^{\circ}$, [131] pp. $\mathbf{H}^{\star}, \mathbf{L}^{\star}, \mathbf{N}^{\star}, \mathbf{S}, \mathbf{S}, \mathbf{S}^{\star}, \mathbf{U}$.

Two versions exist which differ only in the last signature (pp. 121ff).

$\dagger$ (19) [David Silvius,] Oförgripeligit Betenckande / Angående ett Öfer= CONSISTORII [sic] inrättande i Sweriges Ryke [sic] (n. pl.: n. pr., 1730). $8^{\circ}$, [104] pp. $\mathbf{K}^{\star}, \mathbf{L}^{\star}, \mathbf{L i}^{\star}, \mathbf{N}^{\star}, \mathbf{O}^{\star}, \mathbf{S}^{\star}, \mathbf{U}$.

"Apparently printed abroad, perchance at Reval" according to Warmholtz ${ }^{73}$; "printed ... probably abroad, possibly in Riga" as surmised by Nordstrandh ${ }^{74}$; LIBRIS gives Reval as place of publication.

\footnotetext{
71 Aarma, "Rääveli traktaadid," 71, considers this tract to be a translation of Elias Praetorius [Christian Hoburg], Spiegel Der Misbräuche beym Predig=Ampt ... (n. pl.: n. pr., 1644) - a book of no less than 756 pages. The Helsinki union catalogue attributes the book to Otto Heinrich Becker (<https://helka.linneanet.fi/cgi-bin/Pwebrecon. cgi?BBID $=83914>$ [accessed 6 October 2013]) who was born in 1667 and could not have published a book in 1626 ("För Etthundrade Åhr sedan"). Nordstrandh, Den äldre svenska pietismens litteratur, 142, proposes Johan Gezelius junior as a translator and discusses yet other suggestions concerning the authorship put forward in older literature. 72 Interleaved copy (shelfmark: Sv. Teol. Saml.-bd. [28:595]), mostly filled with the words of the biblical passages referred to in the printed text.

73 Warmholtz, Bibliotheca historica, vol. 4, no. 1770: "tyckes vara trykt utrikes, til äfventyrs i Revel".

74 Nordstrandh, Den äldre svenska pietismens litteratur, 214: "trycktes ... troligen utomlands, möjligen i Riga".
} 
KокKUVÕTE: 18. sajandi alguses Tallinnas ilmunud rootsikeelsed pietistlikud traktaadid: taust ja bibliograafiline karjäär

Aastatel 1718-1726 ilmud Tallinna trükkali Johann Köhleri käes alt ligikaudu 17 suhteliselt väikest rootsikeelset pietismiteemalist trükist. Siiani on arvatud, et need raamatud trükiti eesmärgiga toimetada neid Rootsi ja Soome, kus ametivõimud poleks nende trükkimiseks luba andnud. Lisaks on omistatud Köhleri trükikojale veel mõned sarnase sisu, kuid ilmumisandmeteta raamatud.

Käesolev artikkel annab esiteks ülevaate sellest, mis on teada raamatute päritolust. Leitud andmed viitavad hoopis sellele, et raamatud ei olnud esialgu tingimata mõeldud Rootsi ja Soome turu jaoks, vaid leidsid lugejaid hoopis Eestis ja Venemaal. Kaks kõnealustest trükistest andis välja ViruJaagupi kirikuõpeteja Axel Julius Herlin. Ühes raamatus on käsikirjaline märkus, et see osteti Siberis. Veel üks raamat osteti Tallinnas.

Teiseks argumenteeritakse artiklis peamiselt tüpograafilistele andmetele tuginedes, et ilmumisandmeteta trükiste seostamine Köhleri trükikojaga on alusetu. Selle põhjuseks võis olla asjaolu, et kollektsionäärid eelistasid alates 18. sajandist omada rariteetidena just keelatud raamatuid ning mitu põlvkonda bibliograafe ja teadlasi on neid andmeid korranud. Elektrooniliste koondkataloogide tulekuga levib info aina kiiremini ja laiaulatsulikumalt. Autor soovitab sellised seosed kriitiliselt üle vaadata ja seda mitte ainult Tallinna, vaid ka põrandaaluse kirjastamise tähtsamate keskuste nagu Amsterdam puhul. Selleks saab kasutada mitmeid allikaid: trükitähtede ja ornamentide kuju, kirjavahetus autori ja trükkali vahel, arhiiviallikaid või ka autobibliograafiaid.

Artikkel lõpeb Köhleri rootsikeelsete raamatute bibliograafiaga, kaasa arvatud talle siiamaani omistatud trükised. 
